Abstracta Iranica Abstracta Iranica

Revue bibliographique pour le domaine irano-aryen

Volume 28 | 2007

Comptes rendus des publications de 2005

\title{
« Textes ottomans et safavides sur l'annexion de Bassora en 1546 ». Eurasian Studies, III/1, 2004, pp. 1-33
}

\section{Giorgio Rota}

\section{(2) OpenEdition}

\section{Journals}

Édition électronique

URL : http://journals.openedition.org/abstractairanica/17652

DOI : 10.4000/abstractairanica. 17652

ISSN : 1961-960X

Éditeur :

CNRS (UMR 7528 Mondes iraniens et indiens), Éditions de l'IFRI

\section{Édition imprimée}

Date de publication : 15 mai 2007

ISSN : 0240-8910

Référence électronique

Giorgio Rota, « « Textes ottomans et safavides sur l'annexion de Bassora en 1546 ». Eurasian Studies, III/1, 2004, pp. 1-33», Abstracta Iranica [En ligne], Volume 28 | 2007, document 170, mis en ligne le 18 septembre 2007, consulté le 25 septembre 2020. URL : http://journals.openedition.org/ abstractairanica/17652 ; DOI : https://doi.org/10.4000/abstractairanica.17652

Ce document a été généré automatiquement le 25 septembre 2020.

Tous droits réservés 


\title{
« Textes ottomans et safavides sur l'annexion de Bassora en 1546 ». Eurasian Studies, III/1, 2004, pp. 1-33
}

\author{
Giorgio Rota
}

1 With this article, the Authors complete (for the time being, at least) their initial study on "Notes et documents sur le ralliement de la principauté de Basra à l'Empire ottoman (1534-1538)" (Anatolia Moderna - Yeni Anadolu, VI, 1996, pp. 85-95). The bulk of the present article consists of a historical-geographical assessment of the conditions of Lower Iraq on the eve of the Ottoman annexation of Basra in 1546. It is followed by the text of the longest known narration of the events, that is, the relevant passage from the Vienna manuscript of the still unpublished "History of Rüstem Paşa" (Österreichische Nationalbibliothek, ms. 339), transliterated and translated into French. The Authors complemented the information provided by the chronicle of Rüstem Paşa: a) with the translation of the much shorter excerpts offered by three contemporary Persian and Ottoman sources (seemingly, the only ones which paid attention to the events of Basra); and b) with the translation of an Ottoman document listing the rewards (in terms of both increases in timar revenues and appointments to new posts) given to the Ottoman officers who took part in the campaign. This article is of manifest importance, since it sheds light on the history of the region at a time when it was caught in the middle of the conflicting interests of the Ottoman Empire, Safavid Persia, Portugal and, of course, the local Arab tribal and urban elites. In particular, the chronicle of Rüstem Paşa mentions several Arab chiefs and shows well the difficulty of waging war in a natural environment such as that of Lower Iraq. 
INDEX

Thèmes : 4.2.1. Safavides et Qâjârs

\section{AUTEURS}

GIORGIO ROTA

Institut für Iranistik - Wien 